\title{
Portulaca oleracea Affects Muscarinic Receptors of Guinea Pig Tracheal Smooth Muscle
}

\author{
M. HASHEMZEHI, M. R. KHAZDAIR ${ }^{1,2}$, M. KIYANMEHR ${ }^{1}$, V. R. ASKARI ${ }^{3}$ AND M. H. BOSKABADY ${ }^{1 *}$ \\ Department of Physiology, School of Medicine, Jiroft University of Medical Sciences, Jiroft, ${ }^{1}$ Neurogenic \\ Inflammation Research Centre and Dept. of Physiology, School of Medicine, ${ }^{2}$ Student Research Committee, \\ Mashhad University of Medical Sciences, ${ }^{3}$ Student Research Committee, Faculty of Pharmacy, Mashhad \\ University of Medical Sciences, Mashhad, Iran
}

\section{Hashemzehi, et al.: Effect of Portulaca oleracea on Musacrinic Receptors}

\begin{abstract}
The relaxant effect of Portulaca oleracea L. on tracheal smooth muscles has been shown. The effect of the plant on muscarinic receptors of tracheal smooth muscles as one possible mechanism responsible for its relaxant effect was examined. Concentration response curves to methacholine were performed in the presence of three concentrations of aqueous-ethanol extract from aerial part of the plant $(0.25,0.50$ and 1.00 $\mathrm{mg} / \mathrm{ml}), 10 \mathrm{nM}$ atropine, and saline. The values of $\mathrm{EC}_{50}$ (effective concentration causing $\mathbf{5 0 \%}$ of maximum response) and $\mathrm{CR}-1$ (( $\mathrm{EC}_{50}$ of test solutions/ $\mathrm{EC}_{50}$ of saline)-1) were measured. The study was done using three designs as non-incubated (group 1), incubated tissues with propranolol and chlorpheniramine (group 2) and incubated tissues with propranolol (group 3). Concentration-response curves to methacholine were shifted to the right and EC50 methacholine were significantly higher in the presence of atropine, medium and highest extract concentrations in all groups and its low concentration in group 3 compared to saline. In addition, $\mathrm{EC}_{50}$ methacholine in the presence of high extract concentration (27.00 \pm 2.12$)$ in group 2 was greater than its low $(\mathbf{1 0 . 3 3} \pm 1.54)$ and medium $(16.83 \pm 2.52)$ concentrations $(p<0.05)$. The values of the CR-1 obtained in the presence of all extract concentrations in all groups were lower than that of atropine $(P<0.05$ to $\mathbf{P}<\mathbf{0 . 0 0 1}$ ). An inhibitory effect for the extract of $P$. oleracea on muscarinic receptors of tracheal smooth muscles was shown and a histamine $\left(\mathrm{H}_{1}\right)$ receptor blockade was also suggested.
\end{abstract}

Key words: Portulaca oleracea, muscarinic receptor, tracheal smooth muscle, inhibitory effect, aqueousethanol extract

Portulaca oleracea L. is an annual succulent which may reach 15.75 inches in height with alternate leaves clustered at stem joints; the yellow flower plant grows in different areas of the world including north and northwest of $\operatorname{Iran}^{[1]}$. Main active constituents of $P$. oleracea are omega-3 fatty acid, $\alpha$-linolenic acid and eicosa-pentaenoic acid. This plant also contains vitamins (mainly vitamins $\mathrm{A}, \mathrm{C}$ and some vitamin $\mathrm{B}$ ) ${ }^{[2,3]}$. The plant also contains organic acids such as citric, maleic, cyanuric, caffeic acid as well as flavonoids, coumarins, and glycosides ${ }^{[4]}$.

$P$. oleracea has several therapeutic effects including diuretic, antiascorbic, antipyretic, antiinflammatory ${ }^{[5-7]}$. The plant is also used for treatment of type-2 diabetes mellitus patients ${ }^{[8]}$. Different pharmacologic effects of this plant are antiinflammatory, analgesic $^{[6]}$, antioxidant ${ }^{[9-11]}$, potassium channel opener and blood pressure modifier ${ }^{[12]}$, as well as neuropharmacological ${ }^{[13,14]}$, wound healing ${ }^{[15]}$, antibacterial $^{[16]}$ and antipyretic effects ${ }^{[17]}$. The relaxant

*Address for correspondence E-mail: mhboskabady@hotmail.com effect of this plant was studied on skeletal muscles ${ }^{[18]}$ and smooth muscle of small intestine ${ }^{[19]}$. Our previous studies also showed relaxant effect of the plant on tracheal smooth muscle ${ }^{[20]}$ and the possible mechanism of this effect for this plant ${ }^{[21]}$. Antitussive effect of the plant in guinea pigs ${ }^{[7]}$ and its bronchdilatory in asthmatic patients ${ }^{[5]}$ were also demonstrated in our previous experiments.

In the present study, the inhibitory effect of aqueousethanol extract of $P$. oleracea on muscarinic receptors of guinea pigs' tracheal smooth muscles, as one possible mechanism responsible for its relaxant effect was examined.

This is an open access article distributed under terms of the Creative Commons Attribution-NonCommercial-ShareAlike 3.0 License, which allows other the remix, tweak, and build up to the non-commercially, as long as the author is credited and the new creations are licensed under the identical terms.

Accepted 15 Jun 2016

Revised 06 Jun 2016

Received 25 Jan 2016

Indian J Pharm Sci 2016;78(3):388-394 


\section{MATERIALS AND METHODS}

P. oleracea was purchased from the local market in July of 2014, in Mashhad. A voucher specimen was preserved in the Herbarium of the School of Pharmacy, Mashhad University of Medical Sciences (Herbarium No:240-1615-12) which was authenticated at Department of Pharmacognosy.

The aqueous ethanol extract was prepared by using maceration method; $100 \mathrm{~g}$ of powdered aerial part of the plant was subjected to extraction with $50 \%$ ethanol by 3 times for $72 \mathrm{~h}$. The hydro-alcoholic maceration extracts were dried in rotary apparatus with $35^{\circ}$. The yields extract was $21 \% \mathrm{w} / \mathrm{w}$ which stored in $-20^{\circ}$ away from light. For preparation of concentrations, the plant extract was dissolved in normal saline.

\section{Animals and tissue preparations:}

Guinea pigs of both sexes (600-800 g) were used in this study (Razi Institute, Mashhad, Iran). Animals were kept in a temperature controlled room with access to standard food and water ad libitum and maintained at $22 \pm 2^{\circ}$ on a $12 \mathrm{~h}$ light/dark cycle during the study period. Experiments were performed in compliance with the rulings of the Institute of Laboratory Animals Resources, Commission on Life Sciences ${ }^{[22]}$.

Tracheal chains of Dunkin-Hartley guinea pigs were prepared as previously described ${ }^{[23]}$ and suspended in a $10 \mathrm{ml}$ organ bath (organ bath 61300, Bio Science Palmer-Washington, Sheerness, Kent, UK) containing Krebs-Henseleit solution with known composition ${ }^{[23]}$ which was maintained at $37^{\circ}$ and gassed with $95 \% \mathrm{O}_{2}$ and $5 \% \mathrm{CO}_{2}$.

Tissue was suspended under isotonic tension ( $1 \mathrm{~g})$ and allowed to equilibrate for at least $1 \mathrm{~h}$ while it was washed with Krebs solution every $15 \mathrm{~min}$. In each experiment, a contraction was measured using an isotonic transducer (Harvard APP LTD, 50-6360 SINO. 0210) and measured by using a software by a computer (Acer Model No. G781) recording ${ }^{[24]}$. The study was approved by the University's Ethics Committee. The allowance number of the relevant ethical committee for the animal experiments is 910690 .

\section{Protocols:}

The effect of $P$. oleracea on muscarinic receptors was examined as previously described ${ }^{[21]}$. Briefly, tracheal smooth muscle was exposed to $10 \mathrm{nM}$ atropine maleate (Sigma Chemical Ltd UK, Catalogue No. C4915), three concentrations of aqueous-ethanol extract from
P. oleracea $(0.25,0.50$ and $1.00 \mathrm{mg} / \mathrm{ml})$ or saline for $10 \mathrm{~min}$ and then cumulative $\log$ concentration response curve to methacholine $\left(10^{-7}\right.$ to $\left.10^{-3} \mu \mathrm{mol}\right)$ was performed in each cases. The $\mathrm{EC}_{50}$ value (effective concentration of methacholine causing $50 \%$ of maximum response), the maximum responses to methacholine and the slope of the methacholine-response curve of each experiment were measured. In experiments with parallel shift in methacholine-response curve, the concentration-ratio minus one (CR-1) as an index of the competitive antagonism effect was calculated by Eqn. $1^{[24]}$.

$\mathrm{CR}-1=\left(\mathrm{EC}_{50}\right.$ of test solution/ $\mathrm{EC}_{50}$ of saline $)-1$

The study was performed in three experimental designs as, (1) non-incubated tracheal chains (group 1, $\mathrm{n}=6$ ), (2) incubated tissues with $1 \mu \mathrm{M}$ chlorpheniramine (Sigma Chemical Ltd, UK) and $1 \mu \mathrm{M}$ propranolol hydrochloride (Sigma Chemical Ltd, UK) 30 min prior to the beginning and while obtaining methacholineresponse curve (group 2, $\mathrm{n}=6$ ) and (3) incubated tissues with $1 \mu \mathrm{M}$ propranolol hydrochloride (Sigma Chemical Ltd UK) 30 min prior to the beginning and while obtaining methacholine-response curve (group 3, $\mathrm{n}=7$ ). All of the experiments were performed randomly with $1 \mathrm{~h}$ resting period of tracheal chains between each two experiments while washing the tissues every 15 min with Krebs solution.

\section{Statistical analysis:}

All data were expressed as mean $\pm \mathrm{SEM}$. The $\mathrm{EC}_{50}$, the slope, and maximum response obtained in the presence of extract and atropine were compared with those obtained in the presence of saline and (CR-1) obtained in the presence of extract with those obtained in the presence of atropine using the paired t-test. The comparisons of the data of different concentrations of the extract were performed using one-way analysis of variance (ANOVA) with Tukey-Kramer posttest. The values of $\mathrm{EC}_{50}$, the slope, (CR-1), and maximum response obtained in three groups were also compared using ANOVA with Tukey-Kramer posttest. Significance was accepted at $\mathrm{P}<0.05$. Statistical analyses were performed with GraphPad Instat version 3.00 (GraphPad Software, San Diego California USA).

\section{RESULTS AND DISCUSSION}

Cumulative $\log$ concentration-response curves of methacholine obtained in the presence of all concentrations of the extract and atropine showed clear rightward shift compared to that of saline in all three groups of experiments (fig. 1). 

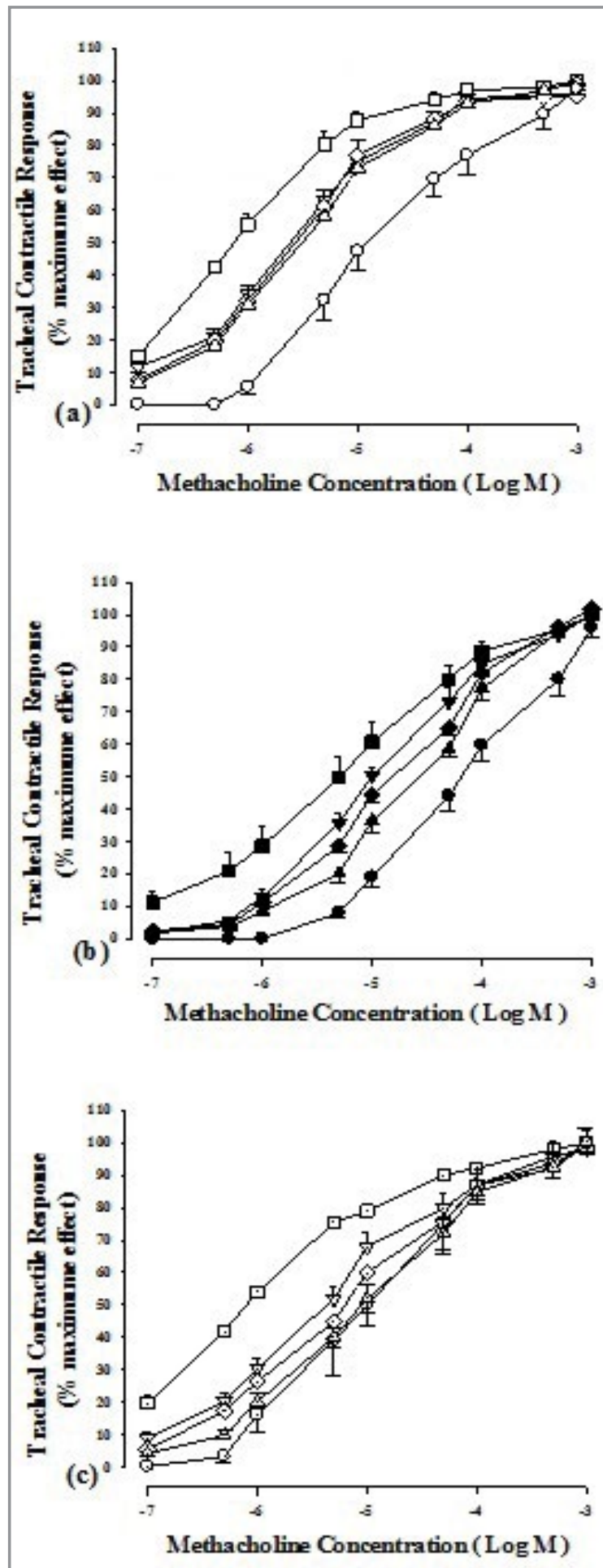

Fig. 1: Cumulative log concentration-response curves of methacholine-induced contraction of guinea pig tracheal smooth muscle.

Cumulative log concentration-response curves of methacholineinduced contraction of guinea pig tracheal smooth muscle in the presence three concentrations of aqueous-ethanol extract from $P$. oleracea, $10 \mathrm{nM}$ atropine ( $\square$ ) and saline (o) in (a) non incubated trachea (group 1, open symbols, $n=6$ ), (b) incubated tissues with $1 \mu \mathrm{M}$ chlorpheniramine and $1 \mu \mathrm{M}$ propranolol (group 2, filled symbols, $n=6$ ) and (c) on tissues incubated with propranolol (Group 3, open symbols with a dot,n=7). Extract $0.25 \mathrm{mg} / \mathrm{ml}(\nabla)$; extract $0.50 \mathrm{mg} / \mathrm{ml},(\diamond) ; \operatorname{extract1} \mathrm{mg} / \mathrm{ml}(\Delta)$
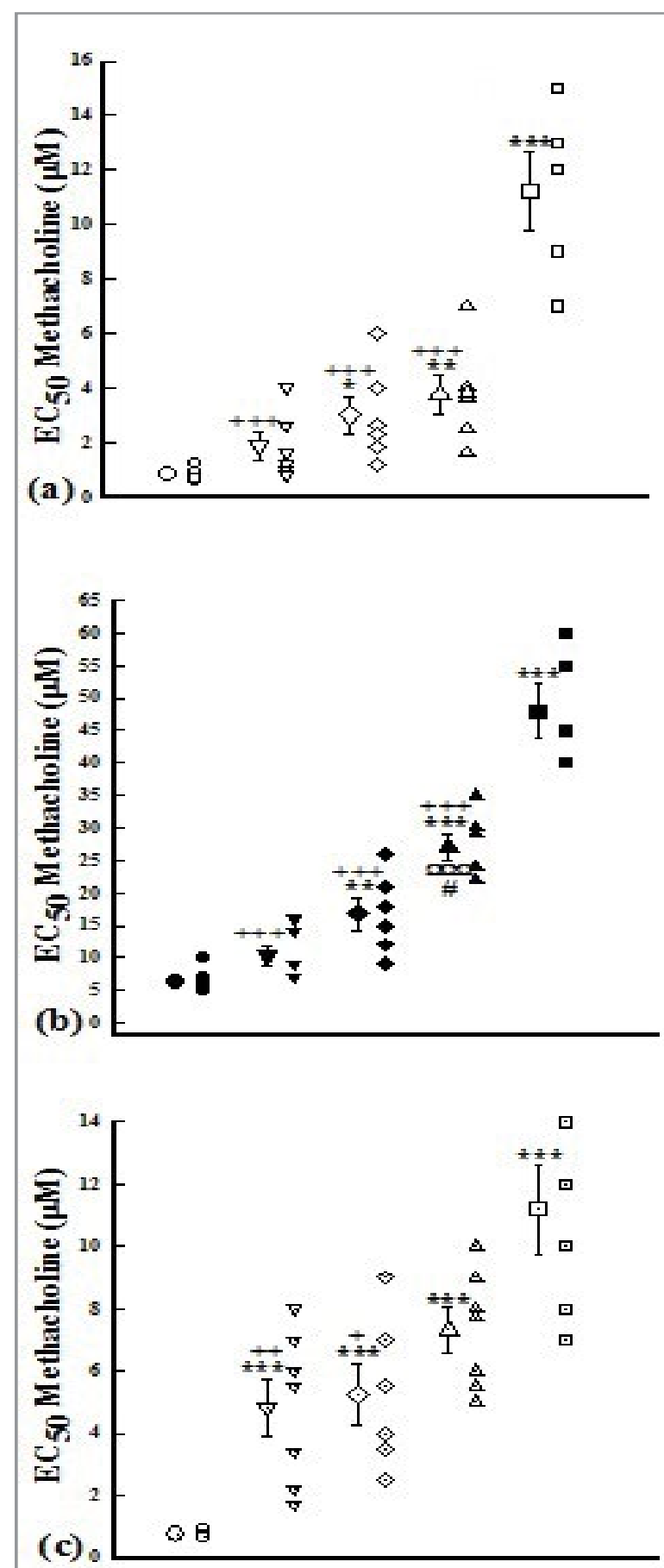

Fig. 2: $\mathrm{EC}_{50}$ values obtained in the three groups.

EC $_{50}$ obtained in the presence of three concentrations of $P$. oleracea extracts, $10 \mathrm{nM}$ atropine and saline in (a) non-incubated tissues, (b) incubated tissues with $1 \mu \mathrm{M}$ chlorpheniramine and 1 $\mu M$ propranolol $n=6$; and (c) with propranolol, $n=7$. *: $P<0.05$, Compared between saline and other solutions. +: $P<0.05$, compared between atropine and other solutions. ' $\Omega$ : $P<0.05$, compared between extract 0.25 vs. 1.00. \#: $P<0.05$, compared in $\mathrm{EC}_{50}$ between extract 0.50 vs. 1.00. Atropine ( $\left.\square\right)$; saline (o); extract $0.25 \mathrm{mg} / \mathrm{ml}(\nabla)$; extract $0.50 \mathrm{mg} / \mathrm{ml}(\diamond)$; extract1 $\mathrm{mg} /$ $\mathbf{m l}(\Delta)$. 
The values of $\mathrm{EC}_{50}$ of methacholine obtained in the presence of atropine, medium and high extract concentrations $(0.50$ and $1.00 \mathrm{mg} / \mathrm{ml})$ in all groups and its low concentration $(0.25 \mathrm{mg} / \mathrm{ml})$ in group 3 were significantly higher than that of saline $(\mathrm{P}<0.05)$. In addition, the values of $\mathrm{EC}_{50}$ of methacholine obtained in the presence of high extract concentration in group 2 was significantly higher than its low and medium concentrations $(\mathrm{P}<0.05$, fig. 2$)$.

There was no statistical difference in maximum response among saline, atropine and extract in three groups of experiment (Table 1). There was no statistical difference in the slope of concentration response curveamong saline, atropine and extract in three group of experiment (Table 2).

The values of CR-1 obtained in the presence of all extract concentrations in three groups were significantly lower than that of atropine $(\mathrm{P}<0.05)$. In addition, the values of CR-1 obtained in the presence of low concentration of the extract in groups 2 and 3 were significantly lower than its high concentration $(\mathrm{P}<0.05)$. The values of $\mathrm{CR}-1$ obtained in the presence of medium concentration of the extract in group 3 were also significantly lower than high concentration of the extract $(\mathrm{P}<0.05$, fig. 3$)$.

There were significant correlations between the values of $\mathrm{EC}_{50}$ and extract concentrations in all three groups $(\mathrm{r}=0.442, \mathrm{P}<0.05, \mathrm{r}=0.740, \mathrm{P}<0.05$ and $\mathrm{r}=0.4772$, $\mathrm{P}<0.05$ in groups 1,2 and 3 , respectively).
In previous studies, the relaxant effect of $P$. oleracea on tracheal smooth muscle was shown ${ }^{[20,21]}$. This effect could be due to several mechanisms including the inhibitory effect of the plant on muscarinic receptors ${ }^{[25]}$. Therefore, in the present study, the inhibitory effect of the extract of the plant on muscarinic receptors of guinea pig tracheal smooth muscle was examined for possible mechanism responsible for its relaxant effect on tracheal smooth muscle. In group 1 experiments (non-incubated tissues) parallel rightward shifts in methacholine log concentration-response curves in the presence of three concentrations of $P$. oleracea, but higher rightward shift in the presence of atropine were shown. $\mathrm{EC}_{50}$ of methacholine obtained in the presence of medium and high concentrations of the extract and atropine was significantly higher than that of saline which may confirm the inhibitory effect of plant concentration at muscarinic receptors. The maximum response to methacholine and slope of methacholine concentration response curves obtained in the presence of the extract concentrations and atropine were not significantly different with those obtained in the presence of saline. These finding may suggested a possible competitive antagonistic effect of the plant at muscarinic receptors of guinea pig trachea smooth muscle ${ }^{[26]}$. However, the values of CR-1 obtained in the presence of three concentrations of the plant were smaller than atropine. The smaller CR-1 values obtained in the presence of the extract concentrations compared to that of atropine indicate lower competitive antagonist effect for the extract than atropine at concentrations used.

\section{TABLE 1: MAXIMUM RESPONSE TO METHACHOLINE IN THREE GROUPS OF EXPERIMENTS}

\begin{tabular}{ccccc}
\hline Solutions & Concentration & Group 1 & Group 2 & Group 3 \\
\hline Saline & & $100.00 \pm 0.00$ & $100.00 \pm 0.00$ & $100.00 \pm 0.00$ \\
Extract & $0.25 \mathrm{mg} / \mathrm{ml}$ & $97.25 \pm 2.413$ & $100.25 \pm 1.702$ & $98.55 \pm 5.611$ \\
& $0.50 \mathrm{mg} / \mathrm{ml}$ & $96.29 \pm 5.611$ & $101.74 \pm 2.459$ & $98.54 \pm 3.617$ \\
Atropine & $1 \mathrm{mg} / \mathrm{ml}$ & $100.80 \pm 2.835$ & $99.82 \pm 1.256$ & $100.37 \pm 4.041$ \\
\hline
\end{tabular}

Data are presented as mean \pm SEM. Group 1, experiments in non-incubated tracheal smooth muscle $(n=6)$; Group 2, experiments in tracheal smooth muscle incubated with propranolol and chlorpheniramine $(n=6)$; Group 3, experiments in tissues incubated with propranolol $(n=7)$. There was no significance difference observed between the data of different solution and different groups.

TABLE 2: SLOPE OF METHACHOLINE RESPONSE CURVES IN THE THREE GROUPS OF EXPERIMENTS

\begin{tabular}{ccccc}
\hline Solutions & Concentration & Group 1 & Group 2 & Group 3 \\
\hline Saline & & $0.98 \pm 0.006$ & $0.96 \pm 0.008$ & $0.95 \pm 0.014$ \\
Extract & $0.25 \mathrm{mg} / \mathrm{ml}$ & $0.92 \pm 0.012$ & $0.97 \pm 0.008$ & $0.97 \pm 0.004$ \\
& $0.50 \mathrm{mg} / \mathrm{ml}$ & $0.96 \pm 0.006$ & $0.98 \pm 0.002$ & $0.98 \pm 0.004$ \\
Atropine & $1 \mathrm{mg} / \mathrm{ml}$ & $0.95 \pm 0.008$ & $0.98 \pm 0.005$ & $0.96 \pm 0.009$ \\
\hline
\end{tabular}

Data are presented as mean $\pm S E M$. Group 1, experiments in non-incubated tracheal smooth muscle $(n=6)$; Group 2, experiments in tracheal smooth muscle incubated with propranolol and chlorpheniramine $(n=6)$; Group 3, experiments in tissues incubated with propranolol $(n=7)$. There was no significance difference observed between the data of different solution and different groups. 


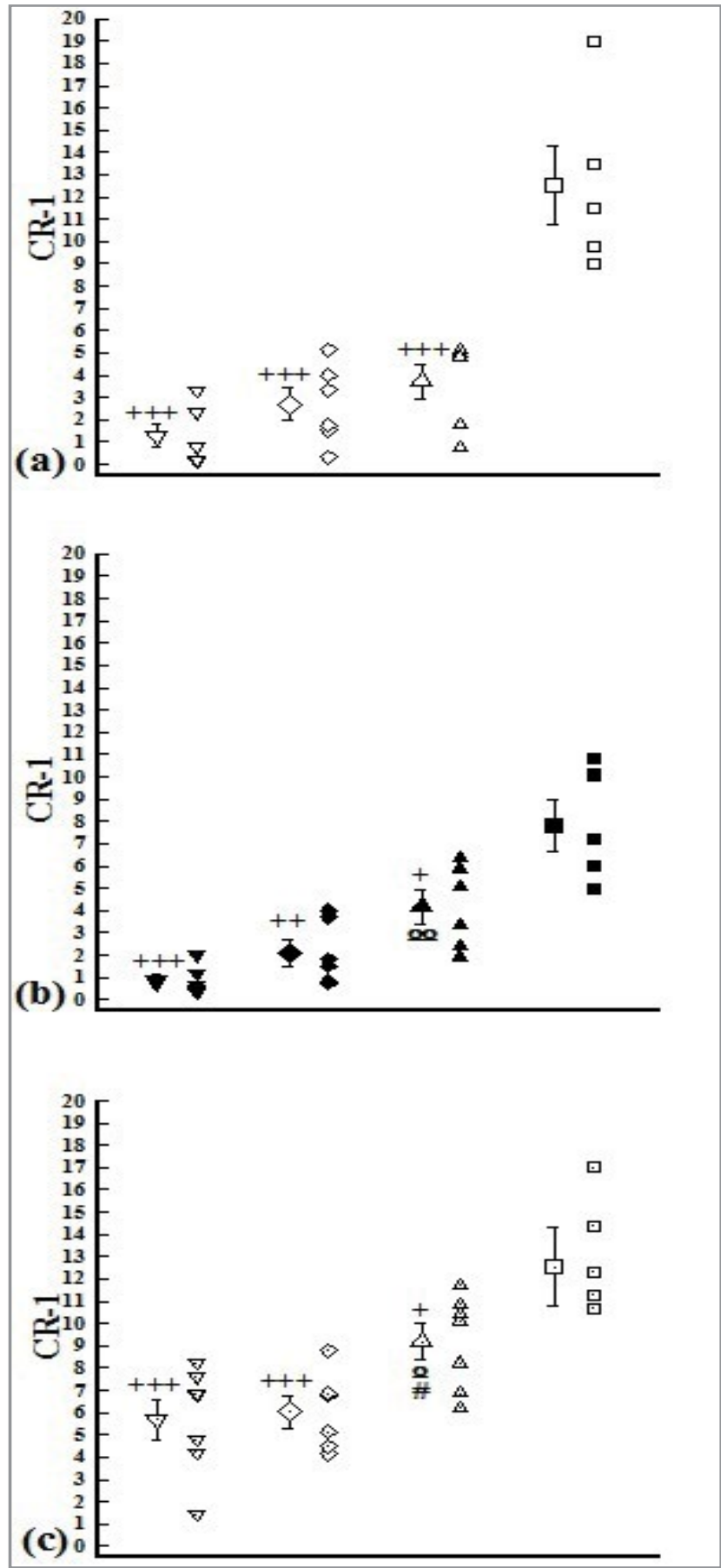

Fig. 3: CR-1 values obtained in the three groups

Values of (CR-1) obtained in the presence of three concentrations of $P$. oleracea extracts and $10 \mathrm{nM}$ atropine in (a) non incubated tissues, $n=6$; (b) incubated tissues with $1 \mu \mathrm{M}$ chlorpheniramine and $1 \mu \mathrm{M}$ propranolol, $n=6$ and (c) tissues incubated with propranolol, $n=7 .+: P<0.05$, compared between atropine and the extract. $\Omega$ : $P<0.05$, compared between extract 0.25 vs. 1.00 . \#: $P<0.05$, compared between extract 0.50 vs. 1.00. Atropine $(\square)$; saline $(0)$; extract $0.25 \mathrm{mg} / \mathrm{ml}(\nabla)$; extract $0.50 \mathrm{mg} / \mathrm{ml}(\diamond)$; extract $1 \mathrm{mg} / \mathrm{ml}(\Delta)$.

To evaluate the contribution of beta-adrenergic stimulatory and/or histamine $\left(\mathrm{H}_{1}\right)$ blocking effect on muscarinic receptor antagonism have seen for the plant in group 1, the inhibitory effect of the plant was also examined in incubated tissues with chlorpheniramine and propranolol to inhibit betaadrenergic and $\mathrm{H}_{1}$ receptors (group 2 experiments). In group 2 experiments also, parallel rightward shifts in methacholine $\log$ concentration-response curves in the present of three concentration of $P$. oleracea and higher rightward shift in the present of atropine were observed. $\mathrm{EC}_{50}$ of methacholine obtained in the presence of medium and high concentrations of extract and atropine were also significantly greater than that of saline. The maximum response to methacholine and slope of methacholine concentration response curves obtained in the presence of the extract concentrations and atropine were also not significantly different with those obtained in the presence of saline. These findings support the possible competitive antagonistic effect of the plant at muscarinic receptors and indicate the absence of major beta-adrenergic stimulatory and/or $\mathrm{H}_{1}$ blocking effect on muscarinic receptor antagonism have seen for the plant in group 1 . The values of $\mathrm{EC}_{50}$ of methacholine obtained in the presence of all solutions in group 2 were significantly higher than group 1 . These results may be due to some interaction(s) among the beta-adrenergic stimulatory and/or $\mathrm{H}_{1}$ and muscarinic receptors. However, the values of CR-1 obtained in the presence of all examined solution were not significantly different with those of group 1 confirming the absence of beta-adrenergic stimulatory and/or $\mathrm{H}_{1}$ blocking effect on muscarinic receptor antagonism seen for the plant.

The inhibitory effect of the plant on muscarinic receptors was also examined on incubated tissues with propranolol only; to evaluate the contribution of betaadrenergic stimulatory alone on antagonism has seen for the extract at muscarinic receptors seen in groups 1 and 2. The results of this group also showed parallel rightward shifts in methacholine log concentrationresponse curves in the present of three concentrations of $P$. oleracea and atropine. $\mathrm{EC}_{50}$ of methacholine obtained in the presence of all extract concentrations and atropine were also significantly higher than that of saline. The maximum response to methacholine and slope of methacholine concentration response curves obtained in the presence of the extract concentrations and atropine were also not significantly different with those obtained in the presence of saline. The values of $\mathrm{EC}_{50}$ of methacholine obtained in the presence of all solutions in group 3 were not significantly different compared to group 1 . These non-significant differences 
in $\mathrm{EC}_{50}$ values between groups 3 and 1 may suggest that higher $\mathrm{EC}_{50}$ values has seen in group 2 is not due to interaction(s) between beta adrenergic stimulatory and muscarinic receptors. The results of group 3 experiments also confirmed a competitive antagonism effect of $P$. oleracea on muscarinic receptor of tracheal smooth muscle.

In all three groups the effect of $P$. oleracea was concentration dependent and there were significant positive correlations between the values of $\mathrm{EC}_{50}$ and the extract concentrations. These findings also confirm the concentration dependent effect of the plant on muscarinic receptors and may support the competitive antagonistic effect of the plant on this receptor type.

These results suggested a competitive antagonistic effect the extract of $P$. oleracea on muscarinic receptors. The results also suggest the absence of beta-adrenergic stimulatory and/or histamine $\left(\mathrm{H}_{1}\right)$ blocking effect on muscarinic receptor antagonism seen for the plant.

\section{Acknowledgment:}

Authors thank Dr. Iranshahi, Associate Professor, Department of Pharmacognosy, School of Pharmacy, Mashhad University of Medical Sciences, Mashhad, Iran for authentication of plant material.

\section{Financial support and sponsorship:}

Nil.

\section{Conflicts of interest:}

There are no conflicts of interest.

\section{REFERENCES}

1. Zargari A. Medicinal plants. Vol 1, Tehran: Tehran University Press; 1993, p. 312-5.

2. Cherukuri VC, Anusha M, Naresh K, Ranjith K, Elumalai A. A review on phytochemical and pharmacological profile of Portulaca oleracea Linn. (PURSLANE). Int J Res Ayur Pharm 2013;4:34.

3. Yang ZJ, Zheng YN, Xiang L. Study on chemical constituents of Portulaca oleracea. Zhong Yao Cai 2007;30:1248-50.

4. Mohamed AI, Hussein AS. Chemical composition of purslane (Portulaca oleracea). Foods Hum Nutr 1994;45:1-9.

5. Malek F, Boskabady MH, Borushaki MT, Tohidi M. Bronchodilatory effect of Portulaca oleracea in airways of asthmatic patients. J Ethnopharmacol 2004;93:57-62.

6. Chan K, Islam MW, Kamil M, Radhakrishnan R, Zakaria $\mathrm{MN}$, Habibullah M, et al. The analgesic and antiinflammatory effects of Portulaca oleracea L. subsp. sativa (Haw.) Celak. J Ethnopharmacol 2000;73:445-51.

7. Borushaki MT, Boskabady MH, Malek F. Antitussive effect of Portulaca oleracea L. in guinea pigs. Iran J Pharm Res 2004;3:187-90.
8. El-Sayed MI. Effects of Portulaca oleracea L. seeds in treatment of type-2 diabetes mellitus patients as adjunctive and alternative therapy. J Ethnopharmacol 2011;137:643-51.

9. Karimi A, Aghasizadeh M, Razavi M, Taghiabadi E. Protective effects of aqueous and ethanol extracts of Nigella sativa L. and Portulaca oleracea L. on free radical induced hemolysis of RBCs. DARU 2011;19:295-300.

10. Yang Z, Liu C, Xiang L, Zheng Y. Phenolic alkaloids as a new class of antioxidants in Portulaca oleracea. Phytother Res 2009;23:1032-5.

11. Behravan J, Mosafa F, Soudmand N, Taghiabadi E, Razavi M, Karimi A. Protective effects of aqueous and ethanol extracts of Portulaca oleracea L. aerial parts on H2O2-induced DNA damage in lymphocytes by comet assay. J Acupunct Meridian Stud 2011;4:193-7.

12. Parry O, Okwuasaba F, Ejike C. Effect of an aqueous extract of Portulaca oleracea leaves on smooth muscle and rat blood pressure. J Ethnopharmacol 1988;22:33-44.

13. Miladi-Gorgi H, Vafaei A, Rashidy-Pour A, Taherian A, Jarrahi M, Emami-Abargoie M. Investigation of anxiolytic effects of the aqueous extract of Portulaca oleracea in mice. Iran J Pharm Res 2004;3:57.

14. Radhakrishnan R, Zakaria M, Islam M, Chen H, Kamil M, Chan K, et al. Neuropharmacological actions of Portulaca oleracea L v. sativa (Hawk). J Ethnopharmacol 2001;76:171-6.

15. Rasheed A, Affif F, Disi A. Simple evaluation of the wound healing activity of the crude extracts of Portulaca oleracea in Mus musculus JVJ-1. J Ethnopharmacol 2003;68:131-6.

16. Zhang X, Ji Y, Qu Z, Xia JC, Wang L. Experimental studies on antibiotic functions of Portulaca oleracea L. in vitro. Chinese $\mathrm{J}$ Microecol 2002;14:277-80.

17. Mohanapriya S, Senthilkumar P, Sivakumar S, Dineshkumar M, Subbhuraam CV. Effects of copper sulfate and copper nitrate in aquatic medium on the restoration potential and accumulation of copper in stem cuttings of the terrestrial medicinal plant, Portulaca oleracea Linn. Environ Monit Assess 2006;121:233-44.

18. Okwuasaba F, Ejike C, Parry O. Skeletal muscle relaxant properties of the aqueous extract of Portulaca oleracea. J Ethnopharmacol 1986;17:139-60.

19. Oluwol FS, oyediji KO. Calcium Ions Influences Smooth Muscle Relaxant Response to Aqueous Extract of Portulaca oleracea. J Med Sci 2007;7:238-42.

20. Boskabadi MH, Borushaki MT, Aslani MR. Relaxant effect of Portulaca. Med hypotheses Res 2004;1:139-47.

21. Boskabady MH, Broshaki MT, Aslani MR, Malek F. Possible mechanisms of relaxant effect of Portulaca oleracea on tracheal chains of guinea pig. Iran J Pharm Res 2004;1:139-47.

22. Clark J, Baldwin R, Bayne K, Brown M, Gebhart G, Gonder $\mathrm{J}$, et al. Guide for the care and use of laboratory animals. Washington, DC: Institute of Laboratory Animal Resources, National Research Council; 1996.

23. Boskabady MH, Kiani S, Aslani MR. Tracheal responsiveness to both isoprenaline and beta2-adrenoreceptor blockade by propranolol in cigarette smoke exposed and sensitized guinea pigs. Respirology 2006;11:572-8.

24. Boskabady MH, Jafari Z, Pouraboli I, Babazade B, Rahbardar MG. Anticholinergic effect of Zataria multiflora Boiss on guinea pig tracheal chains. Nat Prod Res 2012;26:1523-8. 
25. Loenders B, Rampart M, Herman AG. Selective M3 muscarinic receptor antagonists inhibit smooth muscle contraction in rabbit trachea without increasing the release of acetylcholine.
J Pharmacol Exp Therap 1992;263:773-9.

26. Arunlakshana OT, Schild H. Some quantitative uses of drug antagonists. Br J Pharmacol Chemother 1959;14:48-58. 